\title{
Job Insecurity Sebagai Variabel Pemoderasi dalam Hubungan Ketidakpastian Lingkungan Pada Kinerja Pegawai Inspektorat Provinsi Bali
}

\author{
Tjokorda Istri Chitra Anandari \\ Pemayun $^{1}$ \\ Fakultas Ekonomi dan Bisnis \\ Universitas Udayana, Indonesia. \\ Email: tjokitaanandari@gmail.com
}

\author{
I Made Andika Pradnyana Wistawan ${ }^{2}$ \\ Fakultas Ekonomi dan Bisnis \\ Universitas Udayana, Indonesia.
}

\begin{abstract}
ABSTRAK
Tujuan penelitian ini adalah untuk mengetahui pengaruh ketidakpastian lingkungan pada kinerja pegawai dan mengetahui job insecurity dapat memperkuat hubungan antara ketidakpastian limgkungan pada kinerja pegawai Inspektorat Provinsi Bali. Teknik analisis yang digunakan adalah regresi linier berganda. Hasil penelitian menunjukkan bahwa ketidakpastian lingkungan tidak berpengaruh terhadap kinerja pegawai, job insecurity berpengaruh negatif dan signifikan terhadap kinerja pegawai, serta job insecurity memoderasi memperkuat pengaruh antara ketidakpastian lingkungan terhadap kinerja pegawai. Pegawai Inspektorat Provinsi Bali sudah cukup baik dalam melaksanakan tugasnya, sehingga ketidakpastian lingkungan tidak mempengaruhi kinerja. Namun sebaiknya inspektur Inspektorat memberikan motivasi agar dapat menumbuhkan kepercayaan diri pegawainya dan terus meningkatkan kerjasama tim dalam mencari informasi terbaru untuk membuat keputusan dan mewujudkan good governance.
\end{abstract}

Kata Kunci : Kinerja Pegawai; Ketidakpastian Lingkungan; Job Insecurity.

\section{Job Insecurity As a Moderating Variable in the Relationship of Environmental Uncertainty to the Performance of Inspectorates in Bali Province}

\section{ABSTRACT}

The purpose of this study was to determine the effect of environmental uncertainty on employee performance and knowing job insecurity can strengthen the relationship between uncertainty over the performance of employees of the Inspectorate of Bali ProvinceSampling in this study using purposive sampling technique. The analysis technique used is multiple linear regression. The results showed that environmental uncertainty had no effect on employee performance, job insecurity had a negative and significant effect on employee performance, and moderating insecurity jobs strengthened the influence of environmental uncertainty on employee performance. The Inspectorate Staff of the Province of Bali is good enough in carrying out their duties, so that environmental uncertainty does not affect performance. But the Inspectorate inspector should provide motivation to grow the confidence of his employees and continue to improve teamwork in finding the latest information to make decisions and realize good governance.

Keywords: Employee Performance; Environmental Uncertainty; Job Insecurity.

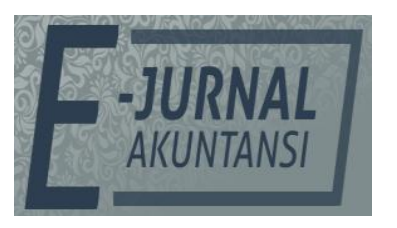

E-JA

e-Jurnal Akuntansi e-ISSN 2302-8556

Vol.298 No. 1

Denpasar, Oktober

2019

Hal. 405-419

Artikel masuk:

07 Mei 2019

Tanggal diterima:

25 Juni 2019 


\section{PENDAHULUAN}

Dalam mencapai suatu tujuan tertentu, diperlukan sebuah rencana yang terstruktur, sumber daya yang tepat guna serta menggunakan metode yang sudah terbukti efektif. Sebuah institusi sebelum menentukan tujuan tertentu sudah semestinya menjabarkan secara rinci latar belakang, menentukan tujuan jangka pendek maupun jangka panjang, menentukan sasaran atau objek dan menentukan metode yang digunakan.

Atas dasar tersebut di atas, dapat disimpulkan bahwa keberhasilan sebuah institusi dalam mencapai tujuan tertentu dipengaruhi oleh faktor lingkungan, faktor job insecurity. Kedua variabel ini berpengaruh satu sama lain. Pada umumnya, sebuah insitusi baik swasta maupun pemerintah mempunyai tata kelola managemen yang sama. Pada institusi swasta, ciri utamanya antara lain : penggunaan sumber daya manusia yang sangat selektif dan profesional, metode yang digunakan sesuai standar operasional prosedur secara tegas, proses monitor dan evaluasi yang disiplin. Pada institusi pemerintah, ciri utamanya antara lain : penggunaan sumber daya manusia seringkali tidak profesional, penentuan jabatan tidak didasarkan kompetensi yang tepat, dan dasar mutasi jabatan yang tidak jelas (Sverke et al., 2002).

Pengaruh ketidakpastian lingkungan di insitusi pemerintah, akan berdampak buruk terhadap kinerja dan prilaku pegawai. Menurut Sora et al. (2010) jabatan atau karier ditentukan oleh hubungan pribadi dengan atasan, kekerabatan partai politik tertentu, adanya hubungan koneksitas, kolusi dan nepotisme. Akibat dari semua ini adalah arah kebijakan dalam mencapai tujuan tertentu di pemerintah sangat tergantung dari periode masa jabatan kepala dari insitusi yang ditunjuk, akan timbul kesimpang siuran informasi dari atasan, serta kontrol penggunaan dana dan waktu yang tidak disiplin. Kondisi ini menimbulkan rawan korupsi.

Ketidakpastian lingkungan adalah persepsi dari anggota organisasi atau pegawai dalam mengantisipasi pengaruh faktor lingkungan terhadap organisasi itu sendiri (Prasetyo, 2001). Duncan (1972) mendefinisikan lingkungan sebagai totalitas faktor sosial dan fisik yang berpengaruh terhadap perilaku pembuatan keputusan seseorang dalam organisasi. Seseorang mengalami ketidakpastian karena ia merasa tidak mampu membedakan antara data yang relevan dengan data yang tidak relevan. Ketidakpastian lingkungan yang tinggi, akan mempengaruhi partisipasi pegawai terhadap kinerja manajerial. Semua tata kelola managemen di pemerintah, seringkali hanya satu arah dari atasan saja tanpa mempertimbangkan konsep demokrasi dan argumentasi yang ideal. Ketidakpastian lingkungan inilah menimbulkan ketidakseimbangan antara tujuan dengan pencapaian hasil akhir. Pengangkatan pegawai di pemerintah dan penempatan di beberapa pos tugas tertentu, sangat menentukan hasil akhir tujuan tertentu yang sudah digariskan. Namun, kinerja pegawai di pemerintah erat terkait dengan etos kerja yang diciptakan oleh kepala institusi bersangkutan. Apabila kontrol dan monitor kerja dilakukan terus menerus dengan disiplin, maka akan menciptakan etos kerja yang positip dan bergairah. Sebaliknya, apabila kontrol dan monitor kerja tidak dilakukan dengan disiplin, pengendalian pegawai yang tidak terstruktur, mutasi pegawai dengan prosedur yang salah, serta pemberian tugas yang tumpangtindih, maka kondisi ini menimbulkan 
ketidak pastian tugas pegawai itu sendiri. Disamping ketidakpastian lingkungan di institusi pemerintah, ada faktor lain yaitu faktor job insecurity. Job insecurity adalah fenomena kompleks yang dapat mempengaruhi kinerja pegawai di pemerintah, bukan hanya di tempat kerja melainkan di luar tempat kerja (Sverke et al., 2002).

Ketidakamanan kerja (job insecurity) mencerminkan serangkaian pandangan individu mengenai kemungkinan terjadinya peristiwa negatif pada pekerjaan, sehingga sangat mungkin perasaan ini akan membawa akibat negatif pada kinerja pegawai sebagai respon emosional utama pada pekerjaannya. Timbulnya job insecurity pada institusi pemerintah merupakan akibat dari perubahan dinamis lingkungan organisasi yang berpotensi menimbulkan ancaman seperti rasa stress, cemas, rasa tidak aman, yang dapat mempengaruhi kelanjutan kontrak psikologik antara pegawai dengan organisasinya. Greenhalgh \& Rosenblatt (1984) dalam kenyataan sehari-hari, kebanyakan job rotasi dan non-job di pemerintah daerah (Pemda) memiliki nuansa politik yang sangat tinggi. Thoha (2002) hal ini mengakibatkan terbentuknya sikap, perilaku, sistem, dan opini para pimpinan bahwa kelembagaan birokrasi pemerintah sudah selayaknya mendukung kekuatan politik yang berkuasa.

Terdapat banyak faktor lain yang dapat menyebabkan para pegawai timbul stress, sehingga mempengaruhi kinerja para pegawai yang berdampak buruk di organisasi pemerintah. Faktor yang dapat mempengaruhi kinerja pegawai itu, harus dikenal terlebih dahulu sebelum menentukan tujuan yang akan dicapai. Oleh karena itu, untuk mendapatkankan hasil kinerja pegawai di institusi pemerintah secara optimal diperlukan beberapa metode untuk menilai kinerja pegawai. Beberapa jenis metode yang dipakai diharapkan dapat memberikan kesimpulan akurat tentang kinerja pegawai yang bersangkutan. Kinerja pegawai yang baik akan menghasilkan produk tujuan yang baik. Kinerja pegawai yang buruk akan berdampak buruk sehingga perlu ditelusuri lebih jauh penyebab utamanya. Penilaian kinerja pegawai di inspektorat hendaknya memiliki berbagai kriteria pengukuran yang dapat dipertanggungjawabkan untuk setiap prestasi kerja. Namun apabila prestasi kerja atau kriteria pengukuran tidak terkait dengan prestasi kinerja pegawai, maka evaluasi tidak menjadi tepat. Penilaian kinerja pegawai yang tepat harus memiliki timbal balik baik bagi pegawai maupun kepada bagian kepegawaian organisasi tersebut.

Penilaian kinerja pegawai di institusi pemerintah sangat penting dilakukan secara teratur karena dinamika masyarakat berubah sangat cepat. Dalam era global dengan tingkat persaingan yang tinggi, para kepala atau manager dituntut mengelola dan memaksimalkan sumber daya manusia dengan mengutamakan humanisme. Untuk dapat mengikuti segala perkembangan ini, diperlukan motivasi tinggi para pegawai di institusi pemerintah. Atasan harus mampu menterjemahkan keinginan standar para pegawai antara lain: gaji atau upah yang baik, pekerjaan yang aman, suasana kerja yang kondusif, penghargaan terhadap pekerjaan yang dilakukan, pimpinan yang adil dan bijaksana, pengarahan dan perintah yang wajar, organisasi atau tempat kerja yang dihargai masyarakat dan mengupayakan insentif yang proporsional dan meningkat secara progresif. Insentif yang diberikan harus sesuai dengan jenjang karir. Insentif ini sangat diperlukan untuk memacu kinerja pegawai di institusi 
pemerintah, supaya selalu berada pada tingkat kinerja pegawai tertinggi (optimal) sesuai kemampuan masing-masing. Apabila insentif yang diberikan dikelola secara benar, maka hal ini membantu organisasi mencapai tujuan dengan lancar. Pegawai tersebut tetap berkarya dengan semangat dan terus meningkatkan produktifitas nya. Namun, apabila insentif tidak dikelola dengan tidak benar maka pegawai negeri tersebut akan mengurangi kinerja mereka dan berusaha mencari tambahan pekerjaan alternatif di luar tugas utamanya. Oleh karena itu, untuk menahan pegawai yang baik ini, maka pihak atasan hendaknya memperhatikan dan memastikan adanya kewajaran pemberian insentif didalam organisasi demi untuk kesejahteraan pegawai dan meningkatkan produktivitas kerjanya. Yang dimaksud dengan insentif di institusi pemerintah adalah imbalan langsung yang diberikan kepada pegawai karena prestasi melebihi standar yang ditentukan oleh instansi tersebut (Panggabean, 2002).

Definisi kinerja pegawai adalah suatu kombinasi dari kemampuan, usaha dan kesempatan yang dapat dinilai dari hasil kerjanya. Hasibuan (2001:34) mengemukakan kinerja pegawai atau prestasi kerja adalah suatu hasil kerja yang dicapai seseorang dalam melaksanakan tugas yang dibebankan kepadanya yang didasarkan atas kecakapan, pengalaman dan kesungguhan serta waktu. Pemberian insentif sangat berpengaruh terhadap kinerja pegawai di institusi pemerintah. Sebagian besar pegawai negeri sipil bekerja dengan disiplin yang tinggi, namun masih terdapat sebagian pegawai lagi yang sering menggunakan waktu kerja untuk hal-hal yang tidak produktif atau bahkan ada yang meninggalkan kantor untuk kepentingan pribadinya. Kondisi seperti ini, menunjukkan rendahnya tingkat disiplin kerja yang pada akhirnya mempengaruhi unit kerja dan lingkungan kerja secara keseluruhan. Rendahnya kinerja pegawai negeri sipil ini tidak dapat dikatakan sebagai akibat dari rendahnya tingkat pendidikan formal para pegawai. Sebagian besar pegawai negeri sipil berpendidikan pada jenjang perguruan tinggi bahkan pasca sarjana, sebagian kecil berasal dari pendidikan SMA. Beberapa faktor lainnya yang juga turut mempengaruhi kinerja pegawai negeri sipil yaitu kurangnya tingkat pendidikan non-formal, antara lain: pelatihan dan kursus-kursus yang diberikan kepada para pegawai, sikap loyal terhadap instansi tempat bekerja, budaya kerja, pengalaman kerja, rendahnya tingkat kedisiplinan pegawai dan rendahnya motivasi. Para pegawai yang memiliki pangkat/golongan yang lebih rendah cenderung di dominasi oleh kehendak atasan yang mengatas namakan kepentingan pribadi diatas kepentingan kantor. Hambatan ini menyulitkan sistem penilaian kinerja pegawai yang obyektif. Pada saat penghitungan remunerasi pegawai di institusi pemerintah, adanya ketidakpastian lingkungan serta adanya faktor job insecurity akan mempengaruhi kinerja pegawai. Pemberian remunerasi pegawai di institusi pemerintah menjadi tidak tepat sasaran yang selanjutnya mempengaruhi tujuan umum insitusi secara keseluruhan. 
Pengawasan merupakan fungsi dari top manajemen dalam setiap organisasi. Demikian halnya dengan organisasi pemerintah, pengawasan merupakan tugas dan tanggung jawab seorang kepala pemerintahan. Tujuan daripada pengawasan adalah memahami dan menemukan kekurangan yang terjadi dalam kinerja yang telah dilakukan sehingga dapat menjadi koreksi di masa depan. Disamping itu, tujuan pengawasan adalah meningkatkan pendayagunaan aparatur negara dalam melaksanakan tugas pemerintahan dalam membangun dan mewujudkan good governance. Dasar hukum pembentukan inspektorat provinsi Bali sebagai salah satu unsur penunjang pemerintah provinsi Bali dan dibentuk berdasarkan Pertauran Daerah Provinsi Bali Nomor 2 Tahun 2008 tentang Organisasi Tata Kerja Perangkat Daerah Provinsi Bali (Lembaran Daerah Provinsi Bali tahun 2008 Nomor 2). Selanjutnya dijabarkan dalam Peraturan Gubenur Bali Nomor 35 tahun 2008 tentang Rincian Tugas Pokok Inspektorat Provinsi Bali (inspektorat.baliprov.go.id).

Tujuan inspektorat provinsi Bali antara lain terwujudnya tertib pelaksanaan administrasi umum dan pemerintahan serta terwujudnya tertib pelaksanaan urusan pemerintahan. Sasaran inpektorat provinsi Bali adalah tertibnya pelaksaan perencanaan dan pelaksannan tugas dan fungsi secara ekonomi, efektif dan efisien didukung dengan peningkatan kualitas dan kinerja aparatur pemerintah daerah, peningkatan tertib perencanaan dan penggunaan anggaran pendapatan belanja pemerintah di daerah, dan tertibnya pertanggungjawaban keuangan dan pengelolaan sarana dan prasarana pemerintah daerah (inspektorat.baliprov.go.id).

Hubungan agensi muncul ketika salah satu pihak (prinsipal) menyewa pihak lain (agen) untuk melaksanakan suatu jasa, di mana prinsipal mendelegasikan wewenang kepada agen untuk membuat keputusan (Anthony \& Govindarajan, 2005:269). Menurut Brigham Eugene \& Houston (2004), hubungan keagenan terjadi ketika prinsipal memberikan wewenang kepada agen baik individu maupun organisasi untuk melakukan sejumlah jasa dan mendelegasikan wewenang kepada agen untuk membuat suatu keputusan. Eisenhardt (1989) teori keagenan memiliki tiga asumsi, yaitu: asumsi tentang sifat manusia, yaitu sifat manusia yang mengutamakan kepentingan sendiri (self interest), keterbatasan rasionalitas atau daya pikir terhadap persepsi masa depan (bounded rationality), dan cenderung untuk menghindari risiko; 2) asumsi tentang keorganisasian, adalah konflik antar anggota organisasi, efisiensi, dan asimetri informasi yang terjadi antara prinsipal dan agen; dan 3) asumsi tentang informasi, adalah informasi dianggap sebagai barang komoditi yang dapat diperjualbelikan.

Dalam rangka memahami corporate governance maka digunakanlah dasar perspektif hubungan keagenan. Jensen \& Meckling (1976) menyatakan bahwa hubungan keagenan adalah sebuah kontrak antara manajer (agen) dengan investor (principal). Terjadinya konflik kepentingan antara pemilik dan agen karena kemungkinan agen bertindak tidak sesuai dengan kepentingan principal, sehingga memicu biaya keagenan (agency cost). 
Dari perspektif teori agen, adanya kesenjangan informasi antara atasan dan bawahan bisa menimbulkan kesenjangan informasi (Suartana, 2010:185). Kesenjangan informasi tersebut bisa dikurangi dengan cara dilibatkannya manajer dalam pengambilan keputusan.

Menurut Suartana (2010:13) menyatakan terdapat 6 (enam) langkah dalam proses pengambilan keputusan secara rasional untuk tiap-tiap situasi yaitu: menentukan permasalah, identifikasi kriterianya, mengukur kinerja, menciptakan alternatif, mengukur nilai alternatif dari setiap kriteria, dan menghitung keputusan yang terbaik atau optional.

Harapan pelanggan adalah dimensi kualitas jadi produk atau jasa yang berkualitas harus memenuhi beberapa dimensi. Dimensi paling utama dalam kualitas adalah kinerja. Dimensi kinerja dalam jasa didefinisikan lebih jauh sebagai atribut daya tanggap, kepastian dan empati (Hansen \& Mowen, 2009:270).

Kinerja merupakan gambaran mengenai tingkat pencapaian pelaksanaan suatu kegiatan atau program atau kebijaksanaan dalam mewujudkan sasaran, tujuan, misi dan visi organisasi yang tertuang dalam perumusan skema strategis (strategic plannning) suatu organisas (Bastian, 2001:239).

Brahmasari (2004:64) mengemukakan bahwa kinerja adalah pencapaian atas tujuan organisasi yang dapat berbentuk output kuantitatif maupun kualitatif, kreatifitas, fleksibilitas yang dapat diandalkan atau hal-hal lain yang diinginkan oleh organisasi.

Cash dan Fischer (1987) dalam (Armanu, 2005:10) mengatakan bahwa kinerja sering disebut performance atau result yang berarti sebuah produk yang dihasilkan oleh individu karyawan. Kinerja karyawan dipengaruhi oleh seberapa banyak karyawan secara individu maupun kelompok memberikan kontribusi kepada institusi misalnya : kuantitas maupun kualitas output, jangka waktu output, kehadiran di tempat kerja dan menumbuhkan sikap kooperatif semua karyawan itu (Mathis \& Jackson, 2002).

Kinerja dapat diartikan kemampuan manajemen dalam melaksanakan tanggungjawabnya terhadap kualitas produk, kuantitas produk, ketepatan waktu produk, pengembangan produk baru, pengembangan personel, pencapaian anggaran, pengurangan biaya (peningkatan pendapatan) dan urusan publik (Nor, 2007).

Kinerja adalah hasil kerja yang dapat dicapai oleh seseorang atau sekelompok orang dalam suatu organisasi sesuai dengan wewenang dan tanggungjawab masing-masing, dalam rangka upaya mencapai tujuan organisasi bersangkutan secara legal dan sesuai dengan moral dan etika (Prawirosentono, 2005).

Kinerja merefleksikan bagaimana karyawan memenuhi keperluan pekerjaan dengan baik. Mathis \& Jackson (2002) mendefinisikan bahwa kinerja pada dasarnya adalah apa yang dilakukan dan tidak dilakukan karyawan. Kinerja karyawan adalah yang mempengaruhi seberapa banyak mereka memberikan kontribusi kepada organisasi. Sumber daya manusia sebagai faktor yang berperan aktif dalam menggerakkan perusahaan/organisasi dalam mencapai tujuannya. Tercapainya tujuan perusahaan hanya dimungkinkan 
karena upaya para pelaku yang terdapat dalam perusahaan, untuk berkinerja dengan baik.

Kinerja perorangan (individual performance) dengan kinerja lembaga (institutional performance) atau kinerja perusahaan (corporate performance) terdapat hubungan yang erat. Dengan perkataan lain bila kinerja karyawan (individual performance) baik maka kemungkinan besar 16 kinerja perusahaan (corporate performance) juga baik. Kinerja seorang karyawan akan baik bila jika mempunyai keahlian (skill) yang tinggi, bersedia bekerja karena gaji atau diberi upah sesuai dengan perjanjian dan mempunyai harapan (expectation) masa depan lebih baik. Pemberdayaan sumberdaya yang dimiliki oleh perusahaan tidak akan terlepas dari peranan manajer selaku pimpinan dalam perusahaan yang membuat suatu kebijaksanaan bisnis.

Kinerja dipengaruhi oleh kinerja organisasi (organizational performance) itu sendiri yang meliputi pengembangan organisasi (organizational development), rencana kompensasi (compensation plan), sistem komunikasi (communication system), gaya manajerial (managerial style), struktur organisasi (organization structure), kebijakan dan prosedur (policies and procedures). Robbins (2003) mengemukakan bahwa istilah lain dari kinerja adalah human output yang dapat diukur dari produktivitas, absensi, turnover, citizenship, dan satisfaction.

Pengertian job insecurity menurut Greenhalgh \& Rosenblatt (1984) dinyatakan sebagai rasa tidak berdaya untuk mempertahankan kelanjutan pekerjaan yang dikehendaki pada kondisi kerja yang mengancam. Job insecurity adalah keadaan ketika karyawan mulai merasa terancam dan tidak berdaya untuk melakukan apapun. Sehingga berdampak pada kesejahteraan karyawan, keluarga dan masalah sosial Owolabi (2011) (dalam Azimi, 2013). Lee et al. (2004) telah menemukan hubungan negatif yang signifikan antara job insecurity dan kesejahteraan karyawan. Smithson \& Lewis (2000) mengartikan ketidakamanan kerja (job insecurity) sebagai kondisi psikologis seseorang (karyawan) yang menunjukkan rasa bingung atau merasa tidak aman dikarenakan kondisi lingkungan yang berubah-ubah (perceived impermanance). Ketidakamanan kerja (job insecurity) mencerminkan serangkaian pandangan individu mengenai kemungkianan terjadinya peristiwa negatif pada pekerjaan, maka sangat mungkin perasaan ini akan membawa akibat negatif pada kinerja karyawan sebagai respon emosional utama pada pekerjaan (Ashford et al., 1989). Sedangkan Greenglass et al. (2002) mendefinisikan job insecurity sebagai ketidakberdayaan untuk mempertahankan kesinambungan yang diinginkan dalam kondisi kerja yang tidak aman. Timbulnya job insecurity akibat perubahan dinamis lingkungan organisasi berpotensi menimbulkan ancaman seperti rasa stress, cemas, rasa tidak aman yang dapat mempengaruhi kelanjutan kontrak psikologik antara karyawan dengan organisasinya (Greenhalgh \& Rosenblatt, 1984). Dalam prakteknya, kebanyakan job rotasi dan non-job di Pemda memiliki nuansa politik yang tinggi. Hal ini mengakibatkan terbentuknya sikap, perilaku, sistem, dan opini para pimpinan bahwa kelembagaan birokrasi pemerintah sudah selayaknya mendukung kekuatan politik yang berkuasa (Thoha, 2002).

Perbedaan antara job insecurity dengan job loss atau kehilangan pekerjaan yaitu job insecurity menimbulkan dampak rasa cemas. Hal ini karena adanya perubahan aturan atau perubahan misi lebih berpengaruh daripada job loss 
(kehilangan pekerjaan) Suatu perubahan aturan dari sebuah institusi mampu merubah sifat dan prilaku individu. Sedangkan pada job loss tidak terpengaruh secara bermakna karena dipengaruhi oleh status pegawai itu (sebagai pegawai tetap atau tidak tetap). Menurut Martínez et al. (2010) job insecurity merupakan proses peristiwa yang berlangsung lama, sedangkan pada job loss merupakan proses yang berlangsung baru. Dampak pada job insecurity lebih banyak bersifat mendadak.

Hubungan ketidakpastian lingkungan dengan kinerja pegawai dapat diukur dengan melihat pengaruhnya terhadap penggunaan serta karakteristik informasi akuntansinya. Dalam kondisi ketidakpastian lingkungan yang rendah (kondisi relatif stabil) individu dapat memprediksi keadaan di masa depan sehingga langkah-langkah yang akan dilakukannya dapat direncanakan lebih akurat (Duncan, 1972). Semakin tinggi ketidakpastian lingkungan, maka semakin rendah kinerja pegawai. Semakin jelas prestasi kinerja pegawai apabila mereka bekerja dalam kondisi stabil. Pada penelitian Sari (2014) menyatakan bahwa ketidakpastian lingkungan tidak berpengaruh signifikan terhadap kinerja suatu perusahaan. Dila Sari \& Yuliansyah (2014) melakukan penelitian mengenai pengaruh ketidakpastian lingkungan terhadap perilaku pegawai pemda dengan ketidakpastian tugas dan job insecurity sebagai variabel moderating menyatakan bahwa ketidakpastian lingkungan tidak berpengaruh positif dan secara statistik tidak signifikan terhadap perilaku pegawai. Berdasarkan dari penelitian sebelumnya, maka dapat disimpulkan hipotesis sabagai berikut:

$\mathrm{H}_{1}$ : Ketidakpastian Lingkungan berpengaruh terhadap Kinerja Pegawai

Pada penelitian Farida (2001) mengenai pengaruh job insecurity dan kompensasi terhadap kepuasaan kerja menunjukan hasil bahwa job insecurity berpengaruh negatif terhadap kepuasan kerja. Nugraha (2010) menyatakan bahwa ketidakamanan kerja (job insecurity) memiliki pengaruh negatif dan signifikan tehadap kinerja karyawan PT. Bank Rakyat Indonesia Cabang Semarang.

$\mathrm{H}_{2}$ : Job Insecurity berpengaruh positif terhadap Kinerja Pegawai.

Penelitian Ratnaningsih (2008) menyatakan job insecurity dapat menjadi pemoderasi antara restrukturisasi dan hubungannya pada turnover intention karyawan. Penelitian Sari \& Yuliansyah (2014)menyatakan bahwa job insecurity berpengaruh positif dan secara statistik sangat signifikan dalam memperkuat hubungan antara ketidakpastian lingkungan dan perilaku pegawai. Hal ini menunjukan bahwa tidak ada dampak langsung dari ketidakpastian lingkungan dan perilaku pegawai. Berdasarkan penelitian sebelumnya, maka hipotesis ketiga dapat disimpulkan sebagai berikut:

$\mathrm{H}_{3}$ : Job Insecurity tidak memoderasi memperkuat antara ketidakpastian lingkungan terhadap Kinerja Pegawai.

\section{METODE PENELITIAN}

Penelitian ini bertujuan untuk menguji hubungan ketidakpastian lingkungan sebagai variabel independen $(X)$ terhadap kinerja pegawai sebagai variabel dependen $(Y)$ dan untuk mengetahui apakah pengaruh tersebut diperlemah atau diperkuat oleh suatu variabel moderasi (Z) yaitu job insecurity. Lokasi penelitian 
dilakukan di Inspektorat Provinsi Bali di Jalan D.I Panjaitan no 14 RenonDenpasar.

Populasi dalam penelitian ini adalah pegawai seluruh instansi yang terdaftar dalam Inspektorat Provinsi Bali. Penelitian ini menggunakan teknik purposive sampling, yaitu pengambilan sampel dengan berdasarkan kriteria yang telah ditentukan oleh peneliti. Kriteria sampel yang digunakan dalam penelitian ini adalah pegawai pemerintah yang terdapat di Inspektorat Provinsi Bali. Responden dari inspektorat yaitu berjumlah 9 (sembilan) orang, yaitu Inspektur, Sekretaris yang membawahi 3 (tiga) orang Sub Bagian, 4 (empat) orang Inspektur Pembantu Wilayah, dan 41 kelompok jabatan fungsional yang terlibat langsung dalam pengawasan minimal 1 (satu) tahun.

Tabel 1. Daftar Jumlah responden

\begin{tabular}{cc}
\hline Jabatan & Jumlah \\
\hline Inspektur & 1 \\
Sekretaris & 1 \\
Sub-Bagian & 3 \\
Inspektur Pembantu Wilayah & 4 \\
Kelompok jabatan fungsional & 41 \\
Total & 50 \\
\hline
\end{tabular}

Sumber: Data Penelitian, 2017

Metode pengumpulan data yang digunakan dalam penelitian ini menggunakan kuisioner dan wawancara.

Moderated Regression Analysis (MRA) bertujuan untuk mengetahui pengaruh variabel moderating dalam memperkuat atau memperlemah hubungan antara variabel dependen dengan variabel independen. Moderated Regression Analysis (MRA) merupakan aplikasi dari regresi linier berganda dimana dalam persamaan regresinya mengandung unsur interaksi.

Model regresi linier berganda dalam penelitian ini dapat diformulasikan sebagai berikut :

$$
Y=\alpha+\beta_{1} X_{1}+\beta_{2} X_{2}+\beta_{3} X_{3}+\beta_{4} X_{1} X_{3}+\sum
$$

Keterangan:

$\mathrm{Y} \quad=$ Variabel dependen kinerja pegawai

a $\quad=$ Konstanta

$\mathrm{X}_{1} \quad=$ Variabel independen ketidakpastian lingkungan

$\mathrm{X}_{2} \quad=$ Variabel moderasi job insecurity

$b_{1}-b_{3} \quad=$ Koefisien regresi

$\mathrm{X}_{1} . \mathrm{X}_{2}=$ Interaksi antara variabel independen ketidakpastian lingkungan dengan variabel moderasi job insecurity

e $\quad=$ Standard error

\section{HASIL DAN PEMBAHASAN}

Responden dari penelitian ini digambarkan secara umum dengan menyajikan karakteristik yang dilihat dari beberapa variabel demografi yaitu usia, jenis kelamin dan pendidikan terakhir. Jumlah responden yang digunakan dalam penelitian ini sebanyak 30 orang responden. Secara rinci, karakteristik responden berdasarkan demografi disajikan pada Tabel 2. 
Tabel 2. Karakteristik Responden Pegawai Inspektorat Provinsi Bali Mengenai Usia, Jenis Kelamin, dan Pendidikan

\begin{tabular}{cccc}
\hline Variabel & Klasifikasi & Jumlah \\
& & Orang & Persentase (\%) \\
\hline \multirow{2}{*}{ Usia (tahun) } & $21-30$ tahun & 3 & 10 \\
& $31-40$ tahun & 12 & 40 \\
& $>40$ tahun & 15 & 50 \\
\multirow{3}{*}{ Jenis kelamin } & Jumlah & 30 & 100 \\
& Laki-laki & 13 & 43,3 \\
\multirow{3}{*}{ Pendidikan Terakhir } & Perempuan & 17 & 56,6 \\
& Jumlah & 30 & 100 \\
& S1 & 20 & 66,7 \\
& S2 & 10 & 33,3 \\
Masa Kerja (tahun) & Jumlah & 30 & 100 \\
& $3-5$ & 3 & 10 \\
& $5-15$ & 12 & 40 \\
& $>15$ & 15 & 50 \\
& Jumlah & 30 & 100 \\
\hline
\end{tabular}

Sumber: Data Penelitian, 2017

Tabel 2 menunjukkan bahwa usia responden Inspektorat Provinsi Bali didominasi oleh pegawai berusia 40 tahun ke atas (50\%), usia 31-40 (40\%), dan (10\%) untuk responden berusia 21-30. Responden didominasi oleh perempuan (56.6\%) dan jumlah pegawai laki-laki adalah (43,3\%), faktor jenis kelamin ini perlu diperhatikan karena kemampuan perempuan dalam menjalankan dan menyelesaikan pekerjaan lebih tepat dan teliti. Pendidikan terakhir yang ditempuh responden didominasi lulusan S1 yaitu $(67,7 \%)$. Hal ini mengindikasikan bahwa pegawai Inspektorat memiliki kompetensi yang sangat profesional dalam menjalankan tugasnya. Masa kerja responden Inspektorat Provinsi Bali lebih banyak memiliki masa kerja diatas 15 tahun sebesar (50\%), yang mengindikasikan bahwa pegawai Inspektorat Provinsi Bali memiliki pengalaman yang baik didalam pencapaian tugasnya.

Penelitian ini menggunakan Moderated Regression Analysis (MRA), dimana MRA dalam persamaan regresinya mengandung unsur interaksi. Analisis ini dibantu dengan menggunakan program SPSS. Persamaan MRA yang sesuai dengan kerangka konseptual penelitian ini, yaitu.

$$
Y=60,492-0,541 X+0,253 Z-0,027(X . Z)+\sum
$$

Persamaan MRA diatas masing-masing memiliki nilai koefisien regresi yang positif, negatif dan nilai konstanta yang positif. Tabel 3 berikut adalah hasil analisis regresi moderasi dalam penelitian ini. 
Tabel 3. Hasil Moderated Regression Analysis

\begin{tabular}{|c|c|c|c|c|c|}
\hline \multirow{2}{*}{ Variabel } & \multicolumn{2}{|c|}{ Unstandarized Coeficients } & $\begin{array}{l}\text { Standarized } \\
\text { Coeficients }\end{array}$ & & \multirow{2}{*}{ Sig. } \\
\hline & B & Std Error & Beta & & \\
\hline (Constant) & 60,492 & 40,538 & & 1,492 & 0,148 \\
\hline $\begin{array}{l}\text { Ketidakpastian } \\
\text { Lingkungan }(X)\end{array}$ & $-0,872$ & 1,163 & $-0,541$ & $-0,750$ & 0,460 \\
\hline Job Insecurity (Z) & 0,132 & 0,339 & 0,253 & 0,388 & 0,701 \\
\hline $\operatorname{si}\left(X^{*} Z\right)$ &, 001 & & & & \\
\hline $\mathrm{R}^{2}$ & 0,585 & & & & \\
\hline F Hitung & 12,233 & & & & \\
\hline Sig. F & 0,0 & & & & \\
\hline \multicolumn{6}{|c|}{ Sumber: Data Penelitian, 2017} \\
\hline \multicolumn{6}{|c|}{$\begin{array}{l}\text { Nilai koefisien ketidakpastian lingkungan sebesar }-0,541 \text { menunjukkan nilai } \\
\text { yang negatif, artinya terdapat pengaruh negatif antara ketidakpastian } \\
\text { lingkungan terhadap kinerja pegawai. Artinya semakin tinggi ketidakpastian } \\
\text { lingkungan, maka semakin rendah kinerja pegawai. Semakin jelas prestasi } \\
\text { kinerja pegawai apabila mereka bekerja dalam kondisi stabil. }\end{array}$} \\
\hline \multicolumn{6}{|c|}{$\begin{array}{l}\text { Nilai koefisien job insecurity sebesar } 0,253 \text { menunjukkan nilai yang positif, } \\
\text { artinya terdapat pengaruh positif atau searah antara job insecurity terhadap } \\
\text { kinerja pegawai yang artinya bila job insecurity meningkat maka kinerja pegawai } \\
\text { juga akan meningkat. }\end{array}$} \\
\hline \multirow{2}{*}{\multicolumn{6}{|c|}{$\begin{array}{l}\text { Nilai koefisien interaksi ketidakpastian lingkungan dan job insecurity sebesar } \\
0,027 \text { menunjukkan nilai yang negatif, artinya tidak terdapat pengaruh positif } \\
\text { atau searah antara interaksi ketidakpastian lingkungan dan job insecurity } \\
\text { terhadap kinerja pegawai. variabel job insecurity sebagai variabel moderasi tidak } \\
\text { memperkuat pengaruh ketidakpastian lingkungan }(X) \text { terhadap kinerja } \\
\text { karyawan }(Y) \text {. }\end{array}$}} \\
\hline & & & & & \\
\hline \multicolumn{6}{|c|}{$\begin{array}{l}\text { Uji keterandalan model atau uji kelayakan model atau yang lebih populer } \\
\text { disebut sebagai uji F (ada juga yang menyebutnya sebagai uji simultan model) } \\
\text { merupakan tahapan awal mengidentifikasi model regresi yang diestimasi layak } \\
\text { atau tidak. Layak (andal) disini maksudnya adalah model yang diestimasi layak } \\
\text { digunakan untuk menjelaskan pengaruh variabel-variabel bebas terhadap } \\
\text { variabel terikat. Nama uji ini disebut sebagai uji F, karena mengikuti mengikuti } \\
\text { distribusi F yang kriteria pengujiannya seperti One Way Anova. }\end{array}$} \\
\hline \multicolumn{6}{|c|}{$\begin{array}{l}\text { Sig. Tabel Anova menunjukkan besarnya angka probabilitas atau } \\
\text { signifikansi pada perhitungan Anova. Nilai yang tertera digunakan untuk uji } \\
\text { kelayanan Model Analisis (dimana sejumlah variabel } x \text { mempengaruhi variabel } \\
\text { y) dengan ketentuan angka probabilitas yang baik untuk digunakan sebagai } \\
\text { model regresi harus }<0,05 \text {. Nilai ini bisa dilihat pada kolom Sig. Jika Sig. }<0,05 \text {, } \\
\text { maka Model Analisis dianggap layak. Jika Sig. }>0,05 \text {, maka Model Analisis } \\
\text { dianggap tidak layak. }\end{array}$} \\
\hline
\end{tabular}


Tabel 4. Uji Anova

\begin{tabular}{lllllll}
\hline Model & & Sum of Squares & Df & Mean Square & $F$ & Sig. \\
\hline 1 & Regression & 1556.884 & 3 & 518.961 & 12.233 & $.000^{\mathrm{a}}$ \\
& Residual & 1103.008 & 26 & 42.423 & & \\
& Total & 2659.891 & 29 & & & \\
&
\end{tabular}

Sumber : Data Penelitian, 2018

Tabel hasil uji anova (UJI F) di atas, diperoleh nilai dalam kelompok pembanding $=3$, nilai dalam kelompok penyebut $=26$, pada alfa $=0.05$ maka nilai F tabelnya adalah F0,05(3,26) $=2,98$. Sedang F hitung $=12,233$. Nilai Fhitung $>$ Ftabel, 12,233 > 2,9812, dengan nilai sig. 0,000 < 0,05. Kesimpulannya, pada kelompok yang diuji memiliki perbedaan yang nyata (signifikan), yang berarti bahwa secara simultan ketidakpastian lingkungan, job insecurity dan interaksi antara ketidakpastian lingkungan dengan job insecurity berpengaruh terhadap kinerja pegawai.

Pada tabel 4 dapat dilihat nilai determinasi $\left(R^{2}\right)$ total sebesar 0,585 mempunyai arti bahwa sebesar 58,5\% variasi Kinerja Pegawai dipengaruhi oleh variasi Ketidakpastian Lingkungan, dan Job Insecurity, sedangkan sisanya sebesar 41,5\% djelaskan oleh faktor lain yang tidak dimasukkan ke dalam model.

Berdasarkan tabel 4 hasil analisis pengaruh Ketidakpastian Lingkungan terhadap Kinerja Pegawai diperoleh nilai Sig. $t$ sebesar 0,460 dengan nilai koefisien beta $-0,541$. Nilai Sig. $\mathrm{t} 0,460>0,05$ mengindikasikan bahwa $\mathrm{H}_{0}$ diterima dan $\mathrm{H}_{1}$ ditolak. Hasil ini mempunyai arti bahwa Ketidakpastian Lingkungan tidak berpengaruh terhadap Kinerja Pegawai.

Berdasarkan tabel 4 hasil analisis pengaruh Job Insecurity terhadap Kinerja Pegawai diperoleh nilai Sig. $t$ sebesar 0,701 dengan nilai koefisien beta 0,253. Nilai Sig. t 0,701 >0,05 mengindikasikan bahwa $\mathrm{H}_{0}$ diterima dan $\mathrm{H}_{1}$ ditolak. Hasil ini mempunyai arti bahwa Job Insecurity berpengaruh negatif terhadap Kinerja Pegawai.

Berdasarkan tabel 4 hasil analisis interaksi antara Job Insecurity dengan ketidakpastian lingkungan terhadap Kinerja Pegawai diperoleh nilai Sig. $t$ sebesar 0,952 dengan nilai koefisien beta -0,027. Nilai Sig. $t$ 0,952 > 0,05 mengindikasikan bahwa $\mathrm{H}_{0}$ diterima dan $\mathrm{H}_{1}$ ditolak. Hasil ini mempunyai arti bahwa Job Insecurity memoderasi memperkuat pengaruh antara ketidakpastian lingkungan terhadap Kinerja Pegawai.

Tujuan dari penelitian ini adalah untuk mengetahui pengaruh ketidakpastian lingkungan terhadap kinerja pegawai. Ditinjau berdasarkan persepsi responden mengenai variabel ketidakpastian lingkungan pada tabel 4.4 yang mengindikasikan bahwa pegawai mengetahui informasi dan tindakan yang diperlukan jika ada tugas yang dibebankan serta dapat memenuhi harapan pihak lain. Hasil yang ditunjukkan pada tabel 4.7 menunjukkan nilai $\beta_{1}$ sebesar -0,541 dengan tingkat signifikansi 0,460 . Hal ini mengindikasikan bahwa variabel ketidakpastian lingkungan tidak mempengaruhi kinerja pegawai Inspektorat Provinsi Bali, sehingga hipotesis pertama $\left(\mathrm{H}_{1}\right)$ ditolak.

Hasil penelitian ini mendukung hipotesis sebelumnya yaitu ketidakpastian lingkungan tidak berpengaruh signifikan terhadap kinerja perusahaan yang dilakukan (Sari, 2014). Sari \& Yuliansyah (2014) menyatakan 
bahwa ketidakpastian lingkungan tidak berpengaruh positif dan secara statistik tidak signifikan terhadap perilaku pegawai pemda.

Persepsi responden job insecurity mengindikasikan bahwa pegawai Inspektorat Provinsi Bali menganggap penting seluruh aspek kerja dan prestasi kerja, tidak menutup kemungkinan dimasa depan terjadi perubahan negatif pada seluruh aspek kerja, sehingga muncul rasa tidak berdaya atau takut terhadap perubahan yang mengancam pekerjaan Hasil perhitungan yang ditunjukkan pada tabel 4.9 menunjukkan $\beta_{2}$ sebesar 0,253 dengan tingkat signifikansi 0,701. Hal ini mengindikasikan bahwa variabel job insecurity mempengaruhi kinerja pegawai Inspektorat Provinsi Bali sehingga hipotesis kedua diterima.

Hasil penelitian ini didukung oleh Farida (2001) yang menyatakan bahwa job insecurity berpengaruh negatif terhadap kepuasan kerja. Nugraha (2010) juga menyebutkan bahwa ketidakamanan kerja memiliki pengaruh negatif dan signifikan terhadap kinerja karyawan PT. Bank Rakyat Indonesia Cabang Semarang.

Ditinjau berdasarkan persepsi responden job insecurity pada tabel 4 mengindikasikan bahwa pegawai Inspektorat Provinsi Bali bahwa responden tidak berdaya menghadapi perubahan yang kemungkinan terjadi dimasa depan karena belum mengetahui metode kerja yang terbaik dan kurangnya informasi untuk membuat keputusan sehingga sulit melakukan penyesuaian dan menilai jika telah membuat keputusan yang benar. Hasil perhitungan uji signifikansi parameter individual (Uji-t) menunjukkan bahwa job insecurity memoderasi memperkuat pengaruh antara ketidakpastian lingkungan dengan kinerja pegawai.

Hasil penelitian ini didukung oleh Ratnaningsih (2008) yang menyatakan job insecurity dapat menjadi pemoderasi antara restrukturisasi dan hubungannya pada turnover intention karyawan. Penelitian ini juga diperkuat oleh Sari \& Yuliansyah (2014) yang menyatakan bahwa Job Insecurity berpengaruh positif dan secara statistik sangat signifikan dalam memperkuat hubungan antara ketidakpastian lingkungan dengan perilaku pegawai pemda.

\section{SIMPULAN}

Berdasarkan hasil analisis penelitian dan hasil pembahasan yang telah dilakukan, maka dapat disimpulkan bahwa ketidakpastian Lingkungan tidak berpengaruh terhadap Kinerja Pegawai. Pegawai Inspektorat Provinsi Bali mengetahui informasi dan tindakan yang diperlukan jika ada tugas yang dibebankan serta dapat memenuhi harapan pihak lain, sehingga mencapai sasaran.

Job Insecurity berpengaruh negatif terhadap Kinerja Pegawai. Kemungkinan dimasa depan terjadi perubahan negatif pada seluruh aspek kerja yang dialami pegawai Inspektorat Provinsi Bali mengakibatkan muncul rasa tidak berdaya atau takut terhadap perubahan yang mengancam pekerjaan.

Job Insecurity memoderasi memperkuat pengaruh antara ketidakpastian lingkungan terhadap kinerja pegawai. Tidak berdaya atau rasa takut yang dihadapi pegawai Inspektorat Provinsi Bali dalam menghadapi perubahan yang kemungkinan terjadi dimasa depan dipengaruhi oleh belum mengetahui metode 
kerja yang terbaik dan kurangnya informasi untuk membuat keputusan sehingga sulit melakukan penyesuaian dan menilai jika telah membuat keputusan yang benar.

Berdasarkan simpulan diatas, maka saran yang dapat diberikan adalah pegawai Inspektorat Provinsi Bali sudah cukup baik dalam melaksanakan semua tugas yang dibebankan sehingga ketidakpastian lingkungan yang dirasakan pegawai tidak mempengaruhi kinerja. Tingkatkan terus metode kerja yang terbaik bagi instansi.

Dalam hal ketidakamanan kerja (Job Insecurity) sebaiknya Inspektur Inspektorat memberikan motivasi positif untuk pegawai yang akan menumbuhkan rasa kepercayaan diri pegawainya sehingga rasa tidak berdaya akan ancaman dimasa depan yang dirasakan pegawai berkurang.

Sebagai usaha meminimalisasi perubahan negatif dimasa depan, sebaiknya pegawai Inspektorat Provinsi Bali terus meningkatkan kerjasama antar pegawai dalam mencari informasi terbaru untuk membuat keputusan sehingga mendapatkan metode kerja yang efektif dan tepat guna untuk membangun dan mewujudkan good governance.

\section{REFERENSI}

Anthony, R. N., \& Govindarajan, V. (2005). Sistem Pengendalian Manajemen. (F. X. K. Tjakrawala \& Krista, Eds.) (11th ed.). Jakarta: Salemba Empat.

Armanu, T. (2005). Hubungan Kepemimpinan,Budaya, Strategi dan Kinerja: Pendekatan Konsep. Jurnal Fakultas Ekonomi Universitas Brawijaya Malang.

Azimi, S. (2013). Partisipasi dan dampak program CSR PTPN VII terhadap taraf hidup masyarakat Gunung Dempo Sumatera Selatan. Institute Pertanian Bogor.

Bastian, I. (2001). Akuntansi Sektor Publik di Indonesia (1st ed.). Yogyakarta: BPFE.

Brahmasari, I. A. (2004). Pengaruh Variabel Budaya Perusahaan terhadap Komitmen Karyawan dan Kinerja Perusahaan Kelompok Penerbitan Pers Jawa Pos. Universitas Airlangga.

Brigham Eugene, F., \& Houston, J. (2004). Fundamentals of Financial Management Dasar-Dasar Manajemen Keuangan (10th ed.). Jakarta: Salemba Empat.

Farida, Y. N. (2001). Pengaruh Job Insecurity dan Kompensasi Terhadap Kepuasan Kerja. Universitas Diponegoro.

Greenglass, E., Burke, R., \& Fiksenbaum, L. (2002). Impact of Restructuring, Job Insecurity and Job Satisfaction in Hospital Nurses. Sress News January, 14(1), $1-10$.

Greenhalgh, L., \& Rosenblatt, Z. (1984). Job insecurity: Toward conceptual clarity. Academy of Management Review, 9(3), 438-448.

Hansen, \& Mowen. (2009). Akuntansi Manajerial (8th ed.). Jakarta: Salemba Empat.

Hasibuan, M. S. P. (2001). Manajemen Sumber Daya. Jakarta: Bumi Aksara.

Inspektorat.baliprov.go.id. inspektorat.bali.

Jensen, M., \& Meckling, W. (1976). Theory of the Firm: Managerial BehaviorAgency Cost, and Ownership Structure. Journal of Finance Economics, 3, 305-360.

Lee, S., Colditz, G. A., Berkman, L. F., \& Kawachi, I. (2004). Prospective study of job insecurity and coronary heart disease in US women. Annals of 
Epidemiology, 14(1), 24-30.

Martínez, G., Cuyper, N. De, \& Witte, H. De. (2010). Review Of The Job Insecurity Literature: The Case Of Latin America.

Mathis, R. L., \& Jackson, J. H. (2002). Human Resoursce Management. Jakarta: Salemba Empat.

Nor, W. (2007). Desentralisasi dan Gaya Kepemimpinan Sebagai Variabel Moderating Dalam Hubungan Partisipasi Anggaran dan Kinerja Manajerial. In Simposium Nasional Akuntasi.

Nugraha, A. (2010). Analisi Pengaruh Ketidakamanan Kerja dan Kepuasan Kopensasi Terhadap Kinerja Karyawan (Studi Pada Karyawan Kontrak PT. Bank Rakyat Indonesia Cabang Semarang Pattimura dan Unit Kerjanya). Universitas Diponegoro.

Panggabean, M. S. (2002). Pengaruh Keadilan Dalam Penggajian dan Perilaku Individu Terhadap Kinerja Dosen Pada Perguruan Tinggi Swasta. Perbanas Institut Jakarta.

Prasetyo, P. P. (2001). Pengaruh Locus of Control Terhadap Hubungan Antara Ketidakpastian Lingkungan Dengan Karakteristik Sistem Informasi Akuntansi Manajemen. Simposium Nasional Akuntansi IV.

Prawirosentono, S. (2005). Manajemen Operasi (4th ed.). Jakarta: Bumi Aksara.

Ratnaningsih, E. (2008). Restrukturisasi Pada Masa Krisis Ekonomi Global Tahun 2008 dalam Hubungannya terhadap Turnover Intention Karyawan dengan Job Insecurity sebagai Variabel Pemoderasi. Akmenika UPY, 3.

Robbins, S. P. (2003). Organizational Behavior (10th ed.). Singapura: Prentice Hall.

Sari, D. M., \& Yuliansyah, L. W. (2014). Pengaruh Ketidakpastian Lingkungan Terhadap Perilaku Pegawai Pemda Dengan Ketidakpastian Tugas Dan Job Insecurity Sebagai Variabel Moderating. SNA 17 Mataram.

Sari, N. (2014). Pengaruh Ketidakpastian Lingkungan Terhadap Kinerja Perusahaan Melalui Karakteristik Informasi Sistem Akuntansi Manajemen Sebagai Variabel Intervening (Studi Empiris Pada Perusahaan Manufaktur Di Kota Padang). Universitas Negeri Malang.

Smithson, J., \& Lewis, S. (2000). Is job insecurity changing the psychological contract? Personnel Review, 29(6), 680-702. https://doi.org/10.1108/00483480010296465

Sora, B., Caballer, A., \& Peiro, J. M. (2010). The consequences of job insecurity for employees: The moderator role of job dependence. International Labour Review, 149(1), 60-72.

Suartana, I. W. (2010). Akuntansi Keperilakuan Teori dan Implementasi. Yogyakarta: Andi.

Sverke, M., Hellgren, J., \& Näswall, K. (2002). No Security: A Meta-analysis and Review of Job Insecurity and Its Consequences. Journal of Occupational Health Psychology, 7(2), 242-264. https:// doi.org/10.1037/1076-8998.7.3.242

Thoha, M. (2002). Reformasi Birokrasi Pemerintah. In Seminar Good Governance. Universitas Gadjah Mada. 